\title{
IMPLEMENTASI MODEL ADDIE DAN KOMPETENSI KEWIRAUSAHAAN DOSEN TERHADAP MOTIVASI WIRAUSAHA MAHASISWA
}

\author{
Indah Purnama Sari, Universitas Indraprasta PGRI \\ zaenimiftah02@gmail.com
}

\begin{abstract}
ABSTRAK
Tujuan penelitian ini adalah untuk mengetahui pengaruh implementasi model ADDIE dan kompetensi kewirausahaan dosen terhadap motivasi wirausaha mahasiswa, baik pengaruh secara parsial maupun simultan. Sampel diambil sejumlah 30 orang secara acak dari 2 kelas yang berbeda yang pernah mengambil mata kuliah kewirausahaan. Data dikumpulkan menggunakan kuesioner. Data kemudian dianalisis dengan metode kuantitatif yaitu analisis regresi linier berganda. Berdasarkan uji asumsi klasik, tidak ditemukan masalah asumsi klasik dalam model regresi. Berdasarkan hasil uji t, ditemukan bahwa variabel implementasi model ADDIE tidak berpengaruh signifikan terhadap motivasi wirausaha mahasiswa, sedangkan variabel kompetensi kewirausahaan dosen berpengaruh signifikan terhadap motivasi wirausaha mahasiswa. Adapun hasil uji $\mathrm{F}$ menunjukkan kedua variabel bebas secara bersama-sama berpengaruh signifikan terhadap motivasi wirausaha. Berdasarkan uji $\mathrm{R}^{2}$ menunjukkan kontribusi variabel implementasi Model ADDIE dan kompetensi kewirausahaan dosen, kecil pada variabel motivasi wirausaha pada mahasiswa. Rekomendasi berdasarkan hasil penelitian adalah lembaga perguruan tinggi perlu mempertimbangkan aspek kompetensi kewirausahaan dosen dalam hal menetapkan dosen pengampu matakuliah kewirausahaan.
\end{abstract}

Kata Kunci: Model ADDIE, Kompetensi Wirausaha Dosen, Motivasi Wirausaha.

\begin{abstract}
The purpose of this study is to determine the effect of the implementation of ADDIE model and entrepreneurship competence of lecturers to student entrepreneur motivation, either partially or simultaneously. Samples were taken by a total of 30 people at random from 2 different classes who had taken entrepreneurship courses. Data were collected using questionnaires. Data then analyzed by quantitative method that is multiple linier regression analysis. Based on the classical assumption test, no classical assumption problem was found in the regression model. Based on the result of $t$ test, it is found that implementation variable of ADDIE model has no significant effect to entrepreneurship motivation of student, while entrepreneurship entrepreneur competence variable has significant effect to entrepreneurship motivation of student. The results of the F test showed that both independent variables together significantly influence the
\end{abstract}


entrepreneurial motivation. Based on $R 2$ test shows the contribution of variable implementation of ADDIE Model and entrepreneurship competence of lecturer, small on variable entrepreneur motivation in student. Recommendations based on the results of research is that universities need to consider aspects of entrepreneurship competence of lecturers in terms of assigning lecturers of entrepreneurship subjects.

Keywords: Model ADDIE, Lecturers Entrepreneurial Competence, Entrepreneurial Motivation.

\section{PENDAHULUAN}

Pada era milenium ini pemerintah masih disibukkan dengan pekerjaan rumah untuk mengurangi angka pengangguran terdidik. Walaupun perkembangan teknologi informasi di zaman sekarang sudah sedemikian pesat hingga melahirkan sejumlah peluang usaha dan mengakibatkan perubahan perilaku konsumsi masyarakat, tampaknya hal ini belum cukup signifikan mampu mengurangi angka pengangguran. Menurut penelitian, hadirnya social media berpengaruh positif dan signifikan meningkatkan motivasi wirausaha (Sari dan Maya, 2017). Sekedar termotivasi rupanya belum cukup, perlu diimplementasikan dalam wujud nyata sebuah usaha bisnis.

Fenomena pengangguran, utamanya pengangguran terdidik sudah lama berlangsung di tanah air, merupakan problematika sosial akut yang perlu ditangani secara sistemik dan sistematik. Para pencari kerja setiap tahun meningkat secara cepat ibarat deret ukur, sedangkan lowongan kerja amat terbatas, terkadang menurun dan jika pun ada lowongan kerja yang tersedia peningkatannya tidak seperti deret ukur melainkan hanyalah deret tambah. Akibatnya terdapat kesenjangan yang lebar antara jumlah pencari kerja dan lowongan kerja. Ironisnya, para pencari kerja itu tidak sedikit yang berasal dari lulusan S1 bahkan S2 perguruan tinggi baik negeri maupun swasta. Jumlah pengangguran intelektual yang berasal dari perguruan tinggi itu semakin hari kian bertambah, sehingga membuat risau banyak kalangan termasuk perguruan tinggi dan pemerintah, dalam hal ini khususnya Kementerian Pendidikan Nasional.

Dimasukkannnya matakuliah kewirausahaan dalam kurikulum Perguruan Tinggi (selanjutnya PT) merupakan salah satu satu upaya pemerintah untuk mengurangi jumlah pengangguran terdidik. Tidak lama setelah kebijakan itu diambil kemudian sejumlah PT mulai menyelenggarakan kuliah kewirausahaan. Bahkan ada PT yang mengalokasikan dua semester untuk mata kuliah kewirausahaan Pelaksanaan matakuliah ini sudah berjalan kurang lebih satu dekade lalu namun ternyata bukan sesuatu yang mudah dilakukan karena matakuliah kewirausahaan tersebut sesungguhnya matakuliah terapan dan oleh pemrakarsa kebijakan kurikulum di PT dimaksudkan untuk menjadikan seorang pebisnis atau entrepreneur (Musnandar, 2014).

Mahasiswa yang menyelesaikan studi S1 nya di PT diharapkan dapat merintis dan membuka usaha sendiri sehingga lulusan S1 yang mencari kerja berkurang karena mereka lebih tertarik membuka lapangan pekerjaan. Tujuan mulia ini tampak indah didengar tetapi sulit untuk diwujudkan karena membawakan matakuliah ini bukan perkara gampang. Dosen pengampu 
matakuliah kewirausahaan harus memiliki kompetensi memadai diantaranya juga telah mempunyai pengalaman berbisnis, jatuh bangun merintis dan mengembangkan usaha dan atau yang bersangkutan terlibat berperan aktif dalam kegiatan di dunia usaha dan industri pada posisi manajerial (Musnandar, 2014).

Sementara itu dosen-dosen di PT pada umumnya adalah dosen yang berkutat dengan persoalan teori, lebih banyak mengerjakan karya tulis daripada melakukan kegiatan praktek bisnis. Oleh karena itu para dosen teori sejati melahap banyak buku untuk dibaca sebelum akhirnya menghasilkan berbagai karya tulis. Pada tataran inilah sebenarnya mereka bekerja. Sedangkan membuat karya tulis dan membuat sebuah bisnis tentu dua hal yang berbeda. Kalau matakuliah kewirausahaan diampu atau dibawakan oleh dosen yang biasa membuat karya tulis maka hasil akhir dari matakuliah terapan bisnis ini tidak akan jauh dari proposal dan rencana bisnis semata karena sang dosen belum memiliki keahlian atau pengalaman di dunia usaha dan industri. Andaikan dosen itu pernah atau sedang terlibat dalam kegiatan konsultasi bisnis sebagai konsultan namun belum ada pengalaman langsung berbisnis maka mereka ini pun kurang pas untuk mengampu matakuliah kewirausahaan.

Masalah ini perlu dicari solusi yang bijak, misalnya pereguruan tinggi menetapkan kebijakan persyaratan khusus bagi calon dosen pengampu mata kuliah kewirausahaan harus memiliki pengalaman bisnis. Cara yang lain misalnya melalui dukungan implementasi model pembelajaran yang inovatif, seperti Model ADDIE. Model ADDIE merupakan singkatan dari Analysis, Design, Development or Production, Implementation or Delivery and Evaluations. Model ADDIE dikembangkan oleh Dick and Carry (1996) dalam (Mulyatiningsih, 2016) untuk merancang sistem pembelajaran.

Dengan demikian, perpaduan antara model pembelajaran inovatif ADDIE dan kompetensi kewirausahaan dosen diharapkan dapat meningkatkan motivasi kewirausahaan bagi mahasiswa.

Berdasarkan uraian diatas peneliti tertarik untuk mengkaji "Implementasi Model ADDIE dan Kompetensi Kewirausahaan Dosen terhadap Motivasi Wirausaha Mahasiswa". Rumusan masalah meliputi: 1) Apakah implementasi model ADDIE berpengaruh signifikan dan positif terhadap motivasi wirausaha mahasiswa?, 2) Apakah kompetensi kewirausahaan dosen berpengaruh signifikan dan positif terhadap motivasi wirausaha mahasiswa?, dan 3) Apakah implementasi model ADDIE dan kompetensi kewirausahaan dosen secara bersama-sama berpengaruh signifikan dan positif terhadap motivasi wirausaha mahasiswa?.

\section{Implementasi Model ADDIE}

ADDIE merupakan singkatan dari Analysis, Design, Development or Production, Implementation or Delivery and Evaluations. Model ADDIE dikembangkan oleh Dick and Carry (1996) dalam (Mulyatiningsih, 2016) untuk merancang sistem pembelajaran. Berikut ini diberikan contoh kegiatan pada setiap tahap pengembangan model atau metode pembelajaran (Mulyatiningsih, 2016), yaitu:

a. Analysis

Pada tahap ini, kegiatan utama adalah menganalisis perlunya 
pengembangan model/metode pembelajaran baru dan menganalisis kelayakan dan syarat-syarat pengembangan model/metode pembelajaran baru. Pengembangan metode pembelajaran baru diawali oleh adanya masalah dalam model/metode pembelajaran yang sudah diterapkan.

Masalah dapat terjadi karena model/metode pembelajaran yang ada sekarang sudah tidak relevan dengan kebutuhan sasaran, lingkungan belajar, teknologi, karakteristik peserta didik, dsb.

Setelah analisis masalah perlunya pengembangan model/metode pembelajaran baru, peneliti juga perlu menganalisis kelayakan dan syaratsyarat pengembangan model/metode pembelajaran baru tersebut. Proses analisis misalnya dilakukan dengan menjawab beberapa pertanyaan berikut ini: (1) apakah model/metode baru mampu mengatasi masalah pembelajaran yang dihadapi, (2) apakah model/metode baru mendapat dukungan fasilitas untuk diterapkan; (3) apakah dosen atau guru mampu menerapkan model/metode pembelajaran baru tersebut Dalam analisis ini, jangan sampai terjadi ada rancangan model/metode yang bagus tetapi tidak dapat diterapkan karena beberapa keterbatasan misalnya saja tidak ada alat atau guru tidak mampu untuk melaksanakannya. Analisis metode pembelajaran baru perlu dilakukan untuk mengetahui kelayakan apabila metode pembelajaran tersebut diterapkan.

b. Design

Dalam perancangan model/metode pembelajaran, tahap desain memiliki kemiripan dengan merancang kegiatan belajar mengajar. Kegiatan ini merupakan proses sistematik yang dimulai dari menetapkan tujuan belajar, merancang skenario atau kegiatan belajar mengajar, merancang perangkat pembelajaran, merancang materi pembelajaran dan alat evaluasi hasil belajar. Rancangan model/metode pembelajaran ini masih bersifat konseptual dan akan mendasari proses pengembangan berikutnya.

\section{c. Development}

Development dalam model ADDIE berisi kegiatan realisasi rancangan produk. Dalam tahap desain, telah disusun kerangka konseptual penerapan model/metode pembelajaran baru. Dalam tahap pengembangan, kerangka yang masih konseptual tersebut direalisasikan menjadi produk yang siap diimplementasikan. Sebagai contoh, apabila pada tahap design telah dirancang penggunaan model/metode baru yang masih konseptual, maka pada tahap pengembangan disiapkan atau dibuat perangkat pembelajaran dengan model/metode baru tersebut seperti RPP, media dan materi pelajaran.

\section{d. Implementation}

Pada tahap ini diimplementasikan rancangan dan metode yang telah dikembangkan pada situasi yang nyata yaitu di kelas. Selama implementasi, rancangan model/metode yang telah dikembangkan diterapkan pada kondisi yang sebenarnya. Materi disampaikan sesuai dengan model/metode baru yang dikembangkan. Setelah penerapan metode kemudian dilakukan evaluasi awal untuk memberi umpan balik pada penerapan model/metode berikutnya

\section{e. Evaluation}

Evaluasi dilakukan dalam dua bentuk yaitu evaluasi formatif dan sumatif. Evaluation formatif dilaksanakan pada setiap akhir tatap muka (mingguan) sedangkan evaluasi sumatif dilakukan setelah kegiatan berakhir secara 
keseluruhan (semester). Evaluasi sumatif mengukur kompetensi akhir dari mata pelajaran atau tujuan pembelajaran yang ingin dicapai.

Hasil evaluasi digunakan untuk memberi umpan balik kepada pihak pengguna model/metode. Revisi dibuat sesuai dengan hasil evaluasi atau kebutuhan yang belum dapat dipenuhi oleh model/metode baru tersebut.

Yang dimaksud dengan implementasi model ADDIE adalah Dosen menggunakan model ADDIE dalam proses pembelajaran, yaitu melakukan analisis masalah dan kebutuhan, mendesain metode pembelajaran yang dipandang tepat, mengembangkan metode, melaksanakan metode yang telah dirancang, dan melakukan evaluasi terkait pelaksanaan metode apakah efektif dalam mencapai tujuan pembelajaran. Untuk mengimplementasikan model ADDIE, dosen perlu melibatkan mahasiswa sebagai user (pengguna) model tersebut sejak awal, yaitu pada saat menganalisis menganalisis kebutuhan mahasiswa terkait materi yang akan disampaikan apakah metode sebelumnya telah membantu mahasiswa mencapai tujuan pembelajaran. Demikian juga dalam hal menganalisis kelayakan metode baru yang akan digunakan, misal ketersediaan fasilitas. Dengan melibatkan mahasiswa, jika terjadi hambatan pada fasilitas, dosen memiliki jalan keluar yang dapat didiskusikan bersamasama dengan mahasiswa. Bahkan mahasiswa dapat dilibatkan untuk bersamasama mendesain dan mengembangkan metode pembelajaran. Hal ini akan membuat mahasiswa merasa 'turut memiliki' metode maupun proses pembelajaran dan akan terlibat aktif pada saat implementasi metode. Kondisi semacam ini ini sesuai dengan paradigma student centered, dimana Dosen semestinya memberikan ruang yang lebih luas bagi mahasiswa untuk mengembangkan kreativitasnya. Terlebih, Universitas Indraprasta PGRI adalah kampus pendidikan yang banyak mencetak calon guru, mahasiswa perlu difasilitasi untuk mampu menghasilkan metode pembelajaran yang kreatif pada saat betul-betul terjun dalam dunia pendidikan.

\section{Kompetensi Kewirausahaan Dosen}

Salah satu sumber masalah pembelajaran kewirausahaan di kampus kurang terasa 'ruh'nya adalah karena minimnya kompetensi kewirausahaan dosen pengampu. Dosen pengampu mata kuliah (kewirausahaan, khususnya) pada umumnya adalah kategori 'dosen penulis' atau 'dosen peneliti', bukan 'dosen pebisnis'. Dosen dengan tipe ini banyak berkutat dengan persoalan teori, lebih banyak mengerjakan karya-karya tulis daripada melakukan kegiatan praktek bisnis. Dalam kegiatan sehari-hari tipe dosen peneliti umumnya berkutat dengan buku dan jurnal ilmiah, dibandingkan mencoba untuk mewujudkan teori bisnis yang sudah dipelajari dalam dunia nyata.

Tipe dosen tentu akan berdampak pada hasil akhir yang akan dicapai pada matakuliah kewirausahaan. Jika matakuliah kewirausahaan diampu atau dibawakan oleh dosen yang biasa membuat karya tulis maka hasil akhir dari matakuliah terapan bisnis ini tidak akan jauh dari proposal dan rencana bisnis semata karena sang dosen belum memiliki keahlian atau pengalaman di dunia usaha dan industri. Bahkan seandainya dosen tersebut pernah atau sedang terlibat dalam kegiatan konsultasi bisnis (sebagai konsultan) namun belum ada pengalaman langsung berbisnis, maka dosen ini pun kurang pas untuk mengampu matakuliah kewirausahaan. Sekali lagi alasannya adalah, belum 
memiliki pengalaman langsung berwirausaha, sehingga dosen tidak mampu memberikan gambaran yang membumi bagaimana cara memulai usaha, bagaimana kiat usaha tetap survive, bagaimana mengembangkan usaha, dan sebagainya, termasuk kisah pahit kegagalan dalam membangun usaha adalah pelajaran berharga yang semestinya dibagikan kepada mahasiswa.

Dosen pengampu matakuliah kewirausahaan harus memiliki kompetensi kewirausahaan yang memadai diantaranya juga telah mempunyai pengalaman berbisnis, jatuh bangun merintis dan mengembangkan usaha dan atau yang bersangkutan terlibat berperan aktif dalam kegiatan di dunia usaha dan industri pada posisi manajerial (Musnandar, 2014). Tipe 'dosen pebisnis' diyakini mampu membuat pembelajaran kewirausahaan lebih memiliki 'ruh', dan akhirnya mampu menularkan gairah (motivasi) wirausaha bagi mahasiswa.

Adapun jika Dosen Kewirausahaan masih merasa kurang dalam pengalaman berbisnis, mahasiswa dapat difasilitasi untuk mengenal tokohtokoh wirausahawan yang telah sukses. Hal ini bisa dilakukan dengan berbagai metode, misalnya ceramah, wawancara tokoh, mendatangkan narasumber, observasi video, menonton video, dan sebagainya.

\section{Motivasi Wirausaha}

Seorang wirausaha tidak terlepas dari motivasi. Motivasi berasal dari kata motif yang berarti suatu keadaan dalam pribadi seseorang yang mendorong individu tersebut untuk melaksanakan aktivitas tertentu guna mencapai suatu tujuan (Basrowi, 2011). Teori motivasi pertama kali dikemukakan oleh Abraham Maslow yang popular dengan sebutan teori Motivasi Hierarki Kebutuhan Maslow. Maslow berpendapat bahwa hierarki kebutuhan manusia dapat dipakai untuk melukiskan dan meramalkan motivasinya (Sari, 2013). Menurut Maslow, kebutuhan manusia bertingkat sesuai dengan tingkatan pemuasannya, yaitu kebutuhan fisik, kebutuhan keamanan, kebutuhan sosial, kebutuhan harga diri, dan kebutuhan aktualisasi diri (Sunarya, Sudaryono, \& Saefullah, 2011).

Teori yang berikutnya adalah Teori Motivasi Berprestasi McClelland. Menurut McClelland dalam (Alma, 2009) pada dasarnya motivasi seseorang ditentukan oleh tiga kebutuhan, yaitu need for power (kebutuhan akan kekuasaan), need for affiliation (kebutuhan akan affiliasi), dan need for achievement (kebutuhan akan keberhasilan).

Selanjutnya, terdapat teori dorongan dan tarikan (Push Theory dan Pull Theory) dari Gilad dan Levine (Widhari \& Suarta, 2012). Menurut Push Theory, setiap individu didorong untuk menjadi wirausahawan oleh faktorfaktor eksternal yang bersifat negatif, seperti ketidakpuasan kerja, kesulitan mendapatkan pekerjaan, gaji yang tidak memadai, atau jadwal kerja yang tidak fleksibel. Sebaliknya, Pull Theory berargumentasi bahwa orang tertarik untuk menjadi wirausahawan karena hasrat akan kemandirian, kebebasan, aktualisasi diri, keberasilan, kekayaan, atau hal lainnya yang cenderung bersifat positif.

Dalam perkembangannya, riset empiris membuktikan bahwa motivasi kewirausahaan lebih diakibatkan oleh faktor tarikan daripada faktor dorongan (Koesworo, Sina, \& Nugeraheni, 2007). Pendapat lain mengatakan bahwa motivasi seseorang untuk menjadi wirausahawan antara lain: kebebasan, impian personal, dan kemandirian (Saiman, 2009). Berdasarkan teori, maka 
dalam penelitian ini mengambil indikator motivasi kewirausahaan dari pendekatan pull theory. Berdasarkan teori, maka dalam penelitian ini yang dimaksud dengan motivasi kewirausahaan adalah dorongan yang kuat untuk berwirausaha. Indikator motivasi kewirausahaan dirumuskan berdasarkan pendekatan pull theory (faktor internal berupa hasrat, keinginan).

\section{METODE PENELITIAN}

Metode yang digunakan dalam penelitian ini adalah metode kuantitatif. Berdasarkan tingkat eksplanasi, penelitian ini termasuk penelitian asosiatif. Variabel yang digunakan dalam penelitian ini adalah implementsi model ADDIE (variabel $\mathrm{X}_{1}$ ), Kompetensi Kewirausahaan Dosen (variabel $\mathrm{X}_{2}$ ), dan Motivasi Wirausaha Mahasiswa (variabel Y). Populasi dalam penelitian ini adalah mahasiswa semester 7 Program Studi Pendidikan Ekonomi UNINDRA yang pernah mendapatkan matakuliah kewirausahaan dan memiliki pengalaman belajar dengan model ADDIE. Jumlah sampel sebanyak 30 mahasiswa diambil dengan teknik simple random sampling.

Metode pengumpulan data yang digunakan dalam penelitian ini adalah metode kuesioner dan metode dokumentasi. Dalam penyebaran kuesioner peneliti melakukan kontak langsung dengan responden sehingga diharapkan responden dengan sukarela akan memberikan data yang obyektif dan cepat, mengisi kuesioner dengan jawaban yang sesungguhnya, serta untuk memastikan kuesioner kembali kepada peneliti dan meminimalkan ketidak kembalian kuesioner.

Studi dokumentasi juga dilakukan dalam penelitian ini dengan pelakukan pengkajian terhadap sejumlah literatur atau kajian empiris yang relevan dengan tema penelitian.

Instrumen pengumpulan data yang digunakan adalah kuesioner. Kuesioner disusun berdasarkan indikator dari tiap variabel penelitian. Adapun skala pengukuran terhadap instrument menggunakan skala likert dengan rentang skor mulai dari 1 sampai dengan 5. Skala likert dalam penelitian ini termasuk ke dalam skala ordinal. Untuk mengukur variabel implementasi model ADDIE, menggunakan indikator dosen menjelaskan metode pembelajaran yang digunakannya, meminta masukan mahasiswa terkait metode pembelajaran, melakukan pengembangan metode sesuai masukan mahasiswa, dan melakukan evaluasi. Untuk mengukur variabel kompetensi kewirausahaan dosen menggunakan indikator: Dosen menjelaskan pengalamannya berwirausaha, menceritakan tokoh-tokoh wirausahawan sukses, serta terlibat aktivitas bisnis. Adapun untuk mengukur variabel motivasi berwirausaha menggunakan indikator: ingin mandiri, menyukai kebebasan, menunjukkan keberhasilan diri, memiliki banyak impian, dan ingin lebih cepat kaya.

Teknik analisis data yang digunakan adalah analisis data kuantitatif deskriptif dengan menggunakan alat bantu SPSS 23.0 for windows. Teknik analisis data meliputi: uji asumsi klasik, analisis regresi linier berganda dan uji goodness of fit model regresi meliputi uji t, uji $F$ dan uji $\mathrm{R}^{2}$. Uji $\mathrm{t}$ digunakan untuk menguji signifikansi pengaruh implementasi ADDIE terhadap motivasi wirausaha, dan untuk menguji signifikansi pengaruh kompetensi kewirausahaan dosen terhadap motivasi wirausaha mahasiswa. Uji F digunakan 
untuk menguji signifikansi variabel implementasi ADDIE dan kompetensi kewirausahaan dosen terhadap motivasi wirausaha mahasiswa.

\section{HASIL PENELITIAN DAN PEMBAHASAN}

Uji asumsi klasik meliputi uji normalitas, uji multikolinieritas, dan uji heteroskedastisitas. Uji normalitas menggunakan uji Kolmogorov Smirnov dengan bantuan program SPSS 23.0 for Windows, mendapatkan hasil nilai Asymp Sig (2-tailed) sebesar 0,200 lebih besar dari tingkat alpha yang ditetapkan yaitu 0,05 . Oleh karena itu dapat dinyatakan bahwa data dari populasi berdistribusi secara normal, dengan demikian asumsi normalitas terpenuhi. Pengujian multikolinieritas dengan menghitung nilai tolerance dan VIF. Didapatkan nilai tolerance 0,868 lebih besar dari 0,10 dan nilai VIF 1,152 lebih kecil dari 10. Oleh karena itu dapat disimpulkan bahwa tidak ada multikolinieritas antara variabel bebas dalam model regresi.

Adapun uji heteroskedastisitas dengan Glejser SPSS, didapatkan hasil signifikansi variabel X1 sebesar 0,626 dan signifikansi variabel X2 sebesar 0,540. Nilai signifikansi keduanya lebih besar dari 0,05 sehingga dapat disimpulkan tidak terjadi heteroskedastisitas . Uji autorelasi menggunakan Uji Durbin Watson, menghasilkan data sebagai berikut: berdasarkan uji Durbin Watson, didapatkan nilai $d w$ 1,559. Pada Tabel dw dengan signifikansi 5\%, nilai diketahui nilai $\mathrm{d}_{\mathrm{L}} 1,2837$ dan nilai du 1,5666. Dengan demikian, $\mathrm{d}_{\mathrm{L}} \leq \mathrm{d}_{\mathrm{w}}$ $\leq \mathrm{du}$ dimana $1,2837 \leq 1,559 \leq 1,5666$ sehingga tidak menghasilkan simpulan yang pasti mengenai ada tidaknya autokorelasi.

Model regresi yang diperoleh berdasarkan hasil penelitian dapat dituliskan dalam bentuk persamaan regresi sebagai berikut:

$\mathrm{Y}=9,064-0,049 \mathrm{X}_{1}+0,593 \mathrm{X}_{2}$. Dari persamaan tersebut, variabel $\mathrm{X}_{1}$ memiliki koefisien regresi dengan arah negatif, sedangkan variabel $\mathrm{X}_{2}$ memiliki koefisien regresi dengan arah positif. Hal ini menunjukkan bahwa semakin tinggi kompetensi kewirausahaan dosen, akan meningkatkan motivasi kewirausahaan dalam diri mahasiswa.

Adapun uji goodness of fit model regresi dilakukan dengan menguji nilai statistik $t$, nilai statistik $F$, dan koefisien determinasi (R2) pada hasil regresi yang telah memenuhi uji asumsi klasik, didapatkan hasil sebagai berikut:

Berdasarkan perhitungan regresi dengan bantuan SPSS diketahui bahwa determinasi (adjusted $\mathrm{R}^{2}$ ) yang diperoleh sebesar 0,147. Hal ini menunjukkan $14,7 \%$ variabel terikat motivasi wirausaha dapat dijelaskan oleh variabel bebas yaitu implementasi model ADDIE dan kompetensi kewirausahaan dosen. Dengan demikian hal ini juga menunjukkan bahwa motivasi wirausaha dapat dijelaskan oleh variabel lainnya sebesar $85,3 \%$.

Lebih lanjut hasil uji t menunjukkan tidak semua variabel bebas memiliki pengaruh signifikan. Uji parsial menunjukkan variabel implementasi ADDIE memiliki t hitung sebesar -0,210 lebih kecil daripada $t$ table 1,697 dengan signifikansi sebesar 0,835 lebih besar dari 0,05 hal ini menunjukkan pengaruh implementasi model ADDIE dalam pembelajaran tidak signifikan . Adapun variable kompetensi kewirausahaan dosen memiliki t hitung sebesar 2,532 lebih besar dari t tabel 1,697 dengan signifikansi 0,017 lebih kecil dari 0,05 
menunjukkan variabel kompetensi kewirausahaan dosen pengaruhnya signifikan terhadap motivasi wirausaha mahasiswa.

Hasil uji F berdasarkan hasil uji ANOVA didapatkan nilai F hitung 3,497 lebih besar dari $\mathrm{F}$ tabel 3,35 dan signifikansi sebesar 0,045 lebih kecil dari 0,05 menunjukkan variabel motivasi wirausaha mahasiswa dapat dijelaskan oleh variabel implementasi model ADDIE dan kompetensi kewirausahaan dosen secara bersama-sama atau dengan kata lain semua variabel bebas secara bersama-sama merupakan penjelas yang signifikan terhadap variabel terikat.

Hasil pengolahan data untuk menguji hipotesis disajikan pada Gambar 1 sebagai berikut.

$$
\mathrm{t}=-0,210(\mathrm{p}=0,835)
$$

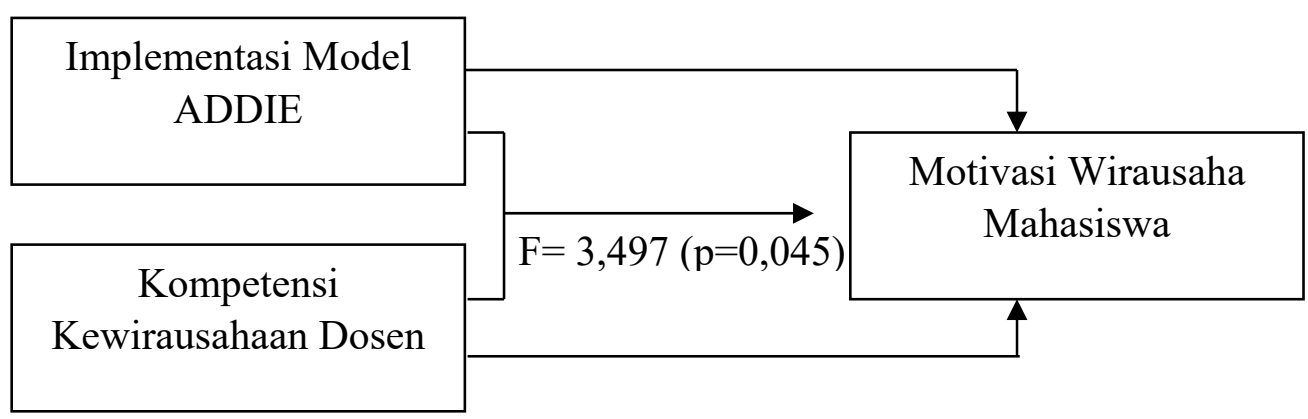

$\mathrm{t}=2,532(\mathrm{p}=0,017)$

\section{Gambar 1. Hasil Pengujian Hipotesis}

Berdasarkan hasil pengujian hipotesis disimpulkan bahwa diantara 3 hipotesis yang diajukan, satu diantaranya ditolak, di dalam penelitian ini tidak terbukti kebenarannya. Variabel kompetensi kewirausahaan dosen terbukti signifikan baik secara parsial maupun secara bersama-sama mempengaruhi motivasi mahasiswa untuk berwirausaha. Namun variabel implementasi model ADDIE secara parsial tidak terbukti signifikan mempengaruhi motivasi berwirausaha sedangkan secara bersama-sama dengan variabel lainnya terbukti mempengaruhi motivasi mahasiswa untuk berwirausaha. Dengan kata lain, hasil penelitian ini menunjukkan bahwa model pembelajaran (ADDIE) khususnya belum mampu meningkatkan motivasi mahasiswa untuk berwirausaha. Implementasi model pembelajaran dan performance dosen pengajar yang dalam hal ini diukur dari kompetensi kewirausahaannya merupakan contoh bentuk stimulasi atau rangsangan dari luar. Jika dikaitkan dengan Push and Pull Theori dari Gilad dan Levine, maka kedua variabel ini termasuk dorongan (push). Riset empiris membuktikan bahwa motivasi kewirausahaan lebih diakibatkan oleh faktor tarikan daripada faktor dorongan (Koesworo, Sina, \& Nugeraheni, 2007). Dengan demikian, hasil penelitian ini semakin menguatkan hasil penelitian sebelumnya.

\section{SIMPULAN}

Simpulan dari penelitian ini adalah: implementasi model ADDIE tidak berpengaruh signifikan terhadap motivasi wirausaha mahasiswa, kompetensi kewirausahaan berpengaruh positif dan signifikan terhadap motivasi wirausaha. 
Adapun kedua variable bebas secara bersama-sama berpengaruh positif dan siginifikan terhadap motivasi wirausaha pada mahasiswa.

Rekomendasi bagi perguruan tinggi dalam hal upaya menumbuhkan motivasi wirausaha bagi mahasiswa adalah memberikan stimulasi berupa ruang, celah, kesempatan, tantangan, dan sejenisnya sehingga mahasiswa menemukan sendiri motivasi atau dorongan untuk menekuni wirausaha. Stimulasi ini misalnya menggiatkan ajang Program Kreativitas MahasiswaKewirausahaan (PKM-K) dari DIKTI, membangun inkubator bisnis, mengadakan kerjasama bisnis dengan pihak luar bahkan luar negeri dimana mahasiswa akan terlibat langsung di dalamnya dan berpartisipasi dalam eventevent bazar atau pameran skala nasional bahkan internasional, serta menggiatkan kembali koperasi mahasiswa melalui perluasan bidang usaha bekerjasama dengan masyarakat setempat untuk menggali potensi home industri maupun industri lokal. Perguruan tinggi juga perlu mempertimbangkan profil dosen pengampu mata kuliah kewirausahaan, utamanya dalam hal kompetensi kewirausahaannya. Akan ideal jika dosen pengampu mata kuliah kewirausahaan dipilih dari seorang 'dosen pebisnis', 'dosen plus wirausahawan' atau dosen yang pernah atau masih aktif dalam suatu kegiatan bisnis dengan jabatan manajerial.

\section{DAFTAR RUJUKAN}

Alma, B. 2009. Kewirausahaan. Bandung: Alfabeta.

Basrowi. 2011. Kewirausahaan untuk Perguruan Tinggi. Bogor: Ghalia Indonesia.

Koesworo, Y., Sina, S. S., \& Nugeraheni, D. 2007. Motivasi Berwirausaha di Kalangan Mahasiswa: aplikasi Theory of Planned Behavior. Jurnal Ekuitas Volume 11 Nomor 2 Maret, 269-291.

Mulyatiningsih, E. 2016. pengembangan-model-pembelajaran.pdf. Retrieved September $30, \quad 2017, \quad$ from http://staff.uny.ac.id: http://staff.uny.ac.id/sites/default/files/pengabdian/dra-endangmulyatiningsih-mpd/7cpengembangan-model-pembelajaran.pdf

Musnandar, A. 2014. opini- kriteria-dosen-kewirausahaan-yang-tepat. Retrieved September 30, 2017, from http://www.umm.ac.id: http://www.umm.ac.id/en/opini/kriteria-dosen-kewirausahaan-yangtepat.html

Saiman, L. 2009. Kewirausahaan Teori, Praktik, dan Kasus-kasus. Jakarta: Salemba Empat.

Sari, I. P. 2013. Pengaruh Keberhasilan Diri, Toleransi akan Risiko, dan Kebebasan dalam Bekerja terhadap Motivasi Berwirausaha pada Mahasiswa Program Studi Pendidikan Ekonomi STKIP PGRI 
Bangkalan. Jurnal Ekonomi Pendidikan dan Kewirausahaan Volume 1 Nomor 1 April , 5-13.

Sari, I.P. dan Maya S. 2017. Social Media dan Social Shopper terhadap Motivasi Wirausaha pada mahasiswa. Prosiding Diskusi Panel Nasional Pendidikan Kewirausahaan. LPPM Universitas Indraprasta PGRI Jakarta, 29 Juli 2017. ISBN: 978-602-50181-0-7. URL http://lppmunindra.ac.id/download-prosiding-kewirausahaan/

Sunarya, P. A., Sudaryono, \& Saefullah, A. 2011. Kewirausahaan. Yogyakarta: ANDI.

Widhari, C. I., \& Suarta, I. K. 2012. Analisis Faktor-faktor yang Memotivasi Mahasiswa Berkeinginan menjadi Wirausaha. Jurnal Bisnis dan Kewirausahaan Volume 8 Nomor 1 Maret, 54-63. 
